\title{
When and how did Cannabis reach Europe and the Iberian Peninsula?
}

Valentí Rull

Botanic Institute of Barcelona (CSIC), Pg. del Migdia s/n, 08038 Barcelona, Spain

vrull@csic.es

\begin{abstract}
Cannabis is among the oldest human domesticates and has been subjected to intensive artificial (human-mediated) selection throughout history to create a wide array of varieties and biotypes for diverse uses, including fiber, food, biofuel, medicine and drugs. This paper briefly reviews the available literature on the taxonomy, evolutionary origin and domestication of this plant, as well as its worldwide dispersal, in both its wild and cultivated forms. Emphasis is placed on Europe and especially on the Iberian Peninsula, which is the main target of this study. Today, it is accepted that Cannabis is a monospecific genus with two subspecies, $C$. sativa subsp. sativa and $C$. sativa subsp. indica, originating in Europe and Asia, respectively, by allopatric differentiation after geographic isolation fostered by Pleistocene glacial-interglacial cycles. Palynological and phylogeographic evidence situates the Cannabis ancestor on the NE Tibetan Plateau during the Oligocene (ca. $28 \mathrm{Ma}$ ). The timing and place of domestication is still a matter of debate between contrasting views that defend single or multiple domestication centers situated in different parts of the Eurasian supercontinent, notably central/southeastern China and the Caucasus region. Recent meta-analyses have suggested that wild Cannabis may have already been spread across Europe in the Pleistocene (ca. $1 \mathrm{Ma}$ ), and its domestication could have occurred during the European Copper/Bronze ages (7-5 kyr $\mathrm{BP})$. According to the available reviews and meta-analyses, preanthropic dispersal of Cannabis into the Iberian Peninsula seems to have occurred only in postglacial times (18.5-15 kyr BP), and the earlier signs of cultivation date to the Early Medieval Ages (ca. $600 \mathrm{CE}$ ). However, the palynological and archaeological evidence used to date is insufficient for a sound assessment, and the development of thorough Iberian databases to address further meta-analysis is essential for more robust conclusions. Some clues are provided for these achievements to be fulfilled.
\end{abstract}

\section{Keywords}

Taxonomy, biogeography, evolution, domestication, dispersal, pollen, archaeology, hemp, drugs 


\section{Introduction}

Since ancient times, Cannabis has been extensively utilized by humans for a variety of uses, such as textiles, paper, food, medicine, biofuel or recreational drugs. Cannabis has been an integral part of human life since the dawn of civilization and continues into the present (e.g., Clarke and Merlin 2013; Fike 2016; Gray et al. 2016a; Grotenhermen and Müller-Vahl 2016). However, research on this plant significantly decreased and almost ceased in the mid-20 ${ }^{\text {th }}$ century when the species and its varieties were declared illegal in most Western countries, regardless of the concentrations of psychoactive compounds (Duvall 2014; Warf 2014). Therefore, one of the most ancient crops, long-valued for its multiple uses, became largely ignored during the last 50 years. Thus, compared with other crop plants, Cannabis has not fully benefited from modern scientific technologies, which has created a major knowledge gap that remains to be filled (Gray et al. 2016b).

The last decade has witnessed a revival of interest in Cannabis research, especially in relation to the genetic and phytochemical features of the different varieties and to its evolutionary origin, domestication and further geographic diffusion (e.g., Clarke and Merlin 2013; Small 2015; Gray et al. 2016b; Vergara et al. 2016). For example, the use of modern methods of molecular analysis has helped clarify the taxonomy of the Cannabis complex and its genetic modifications over time as a result of artificial (human-mediated) selection during the domestication process (Clarke and Merlin 2016). Palynological and archaeological records have been used mostly to identify the center of origin of Cannabis, its center of domestication and further human-driven diffusion patterns throughout the world. Modern global and regional databases and associated handling facilities, notably geographic information system (GIS) tools, have been instrumental in this type of research (McPartland 2020).

This paper briefly reviews the available information on the center of origin and the center of domestication of Cannabis and its further worldwide dispersal, with a focus on Europe, where spatiotemporal diffusion patterns remain controversial, and the Iberian Peninsula, which represents a knowledge gap regarding the tempo and mode of Cannabis arrival and diffusion. This paper begins with a brief section regarding the current state of Cannabis taxonomy, ecology, phenology and uses. The next section discusses the evolutionary center of origin and the time of appearance of the original wild Cannabis, followed by similar geographic and chronological considerations on Cannabis domestication and diffusion of its cultivated forms. The next section focuses on Europe, where domestication and diffusion patterns are still under discussion. The last section highlights the scarcity of information in regard to the Iberian Peninsula, in comparison with other European regions, evaluates the potential causes for this paucity and suggests how further research could contribute to bridging this knowledge gap.

\section{Present-day status}

The genus Cannabis is in the family Cannabaceae, with 11 genera and approximately 170 species. Discussions on the existence of one ( $C$. sativa) or two species ( $C$. sativa and $C$. indica) started during the time of Linnaeus and Lamarck and have continued until very recently. Some morphological differences exist between the two taxa, as C. sativa is taller with a fibrous stalk, whereas $C$. indica is shorter with a woody stalk. There are also phytochemical divergences, as manifested in the tetrahydrocannabinol/cannabidiol (THC/CBD) ratio, which is higher in $C$. sativa. The discontinuous geographic ranges - the sativa lineage in Europe and the indica lineage in Asia - would also support the occurrence of two different taxa within Cannabis. The question is whether these differences qualify for defining two separate species or two subspecific taxa. Using quantitative criteria based on key molecular DNA sequences (DNA barcode), McPartland (2018) concluded that the genetic differences are in the rank of 
subspecies and that the proper nomenclature is $C$. sativa subsp. sativa and $C$. sativa subsp. indica. Therefore, Cannabis is now considered a monospecific genus (Barcaccia et al. 2020; Kovalchuck et al. 2020).

A number of new varieties have been obtained from these two original subspecies by artificial selection, which have different morphologies, phytochemical compositions, geographic distributions and uses (Clarke and Merlin 2016; Lynch et al. 2016; Rahn et al. 2016). According to Small (2015), the consequences of artificial selection make it impossible to determine if unaltered primeval or ancestral populations still exist. This author recommends that $C$. sativa be recognized as a single species with a narcotic subspecies (drug) and a non-narcotic subspecies (hemp), each with domesticated and ruderal varieties. A similar approach is the definition of four major biotypes of cultivated Cannabis with morphological and chemical differences submitted to different uses, either fiber/oil or drug production (Table 1). There is also a hybrid between NLD and BLD, known as "Sinsemilla", which is highly psychoactive (high THC and low CBD) and, hence, is used mainly as a drug. The "Sinsemilla" cultivars were developed in the New World and diffused worldwide. In contrast to the former biotypes, this hybrid is only cultivated, with no feral escapes or ruderal populations. The current distribution of these biotypes is shown in Fig. 1.

Cannabis sativa is a sun-loving (heliotropic) species that requires well-drained and nitrogenrich soils, warmth and moisture. Therefore, most natural populations are found seasonally across accommodating northern temperate latitudes. This plant grows well along exposed riverbanks, lakesides, margins of agricultural lands and other areas disturbed by humans. Cannabis plants are annual and usually dioecious, as determined by $\mathrm{X}$ and $\mathrm{Y}$ chromosomes, and anemophylous (wind-pollinated). The annual cycle extends from spring (germination) to summer (fast juvenile growing) and autumn (flowering). Male plants, which are slightly taller than female plants, die shortly before pollination. Female plants ripen viable seeds just before the arrival of winter killing frosts. Seed dissemination is carried out mostly by wind or feeding birds. During germination, seeds are surrounded by bracts with hairs that produce a resinous blend of cannabinoids and aromatic compounds as secondary metabolites, which are believed to protect seeds against pests and pathogens. Cannabinols may be psychoactive (THC) or not psychoactive (CBD) for humans (Small 2015; Clarke and Merlin 2016).

Almost all parts of the Cannabis plants are utilized for a variety of uses (Table 2). For example, stem bark and fiber are used for cordage, woven textiles, building materials, paper, animal bedding and fuel. Seeds and seed oils are used for human food, animal feed, industrial feedstock and fuel. Female flowers and seeds are used for medicine or recreational drugs. All parts of the plant, primarily bark, seeds and female flowers, are used in ritual and social activities (healing and life cycle rituals, inebriation). Cannabis populations may also be used for environmentally related activities, such as the control of soil erosion and to increase $\mathrm{CO}_{2}$ sequestration. Aesthetic and educational applications include botanical gardens and the iconic character of the plant as a symbol of a very ancient crop deeply rooted in human culture (Gray et al. 2016b). An extensive database on the traditional uses of Cannabis (CANNUSE) is available at http://cannusedb.csic.es/. See Balant et al. (2021) for detailed explanations on this database.

\section{Time and place of origin}

Early attempts to identify the place of origin of wild Cannabis prior to human contact were based on the geographic distribution of its wild, cultivated and ruderal populations, combined with the known ecological requirements and reproductive strategies. However, the distribution of this plant and its biotypes/varieties is closely associated with human 
settlements and trade routes, and therefore, the original native range is obscured (Clarke and Merlin 2013). In spite of this, a broad area referred to as Central Asia (presently China) was proposed as the center of origin of Cannabis (Schultes 1969; Merlin 1972). Another, less generally accepted, possibility mentioned was South Asia (presently India). Regarding timing, accepting that the Central Asian steppes were colonized by humans by 35,000 years ago (Wells 2002; Finlayson 2005), it has been assumed that wild Cannabis could have originated earlier. These hypotheses, however, were based on circumstantial evidence, and robust empirical evidence was lacking. This empirical evidence was provided by the fossil record and the use of time-calibrated molecular DNA phylogenies.

The macrofossil record of Cannabis is relatively scarce and consists of only a few leaf and fruit/seed impressions with ages ranging between the Oligocene and the late Miocene (McPartland et al. 2019). However, microfossils, specifically pollen, are abundant and widespread and have commonly been utilized to reliably reconstruct the history of Cannabis. Nevertheless, the identification of Cannabis pollen deserves special attention because of its similarity with other members of the family Cannabaceae, especially Humulus (hop), a sister genus that bears contrasting ecological requirements and cultural connotations. Therefore, inaccurate identification might lead to erroneous conclusions (Rull and Vegas-Vilarrúbia 2014). This is why different authors have used broader taxonomic categories for this pollen type, such as Cannabis-type, Cannabis/Humulus or Cannabaceae. In addition, it is unclear whether pollen from wild and cultivated Cannabis may be distinguished morphologically.

Several morphological details have been suggested to be useful to differentiate Cannabis and Humulus pollen. Godwin (1967) emphasized several differential characteristics of the pore complex. Further statistical studies revealed that Cannabis pollen is generally larger than Humulus, but this character alone was not sufficient to allow reliable separation (Whittington and Edwards 1989; Whittington and Gordon 1987). Pollen size also seems to be an unreliable parameter to separate wild from cultivated Cannabis (review in McPartland et al. 2018). The combination of pore complexes and size seems to provide a more reliable, yet not universally accepted, identification criterion to differentiate between Cannabis and Humulus pollen (Fleming and Clarke 1998; Mercuri et al. 2002).

However, even in the case of conclusive Cannabis pollen identifications, comparisons with studies referring to this pollen type as Cannabis-type, Cannabis/Humulus or Cannabaceae remain problematic, which may be a handicap for the development of meta-analyses aimed at reconstructing past biogeographic and cultural patterns. Recently, some meta-analyses have been conducted using different criteria, such as considering the entire Cannabis/Humulus complex or taking into account only those studies that explicitly identified Cannabis pollen (Clarke and Merlin 2013; Long et al. 2017). These approaches tend to overestimate or underestimate the actual pollen record of Cannabis.

A different approach, called here the assemblage approach, has recently been proposed by McPartland et al. (2018). These authors noted that wild C. sativa is typical of open temperate steppe habitats dominated by grasses, chenopods and Artemisia, whereas Humulus is a vine plant that requires trees to climb and is common in temperate deciduous forests dominated by alder (Alnus), willow (Salix) and poplar (Populus). A third assemblage corresponds to cultivated Cannabis, which is usually found together with cultivated cereals such as Avena (oats), Hordeum (barley), Secale (rye) and Triticum (wheat), as well weeds such as Centaurea (cornflowers) or Scleranthus (knawels) species. Using these phytosociological affinities, McPartland et al. (2018) attributed the Cannabis-like pollen types recorded in the literature to wild Cannabis if this pollen occurred together with steppe assemblages; to cultivated Cannabis when it was part of crop assemblages; or to Humulus if the dominant pollen assemblage 
corresponded to temperate deciduous forests. Based on these premises, these authors developed a more complicated identification algorithm that also considers the relationship between arboreal (AP) and nonarboreal (NAP) pollen (Fig. 2).

Using these criteria, the oldest known pollen compatible with Cannabis was found in $19.6 \mathrm{Ma}$ old (early Miocene) rocks from the NE Tibetan Plateau (Ningxia, China), which was proposed as the center of origin of Cannabis (McPartland et al. 2019). Interestingly, this proposal generally coincides with the former hypothesis based on indirect biogeographic evidence. Regarding timing, the use of DNA molecular phylogenies calibrated with fossils of related genera such as Humulus, Celtis, Morus and Ficus (Fig. 3) allowed us to estimate the age of divergence of Cannabis and Humulus to $27.8 \mathrm{Ma}$ (mid-Oligocene). Using the same DNA phylogeny and the associated molecular clock, the divergence between $C$. indica (or $C$. sativa subsp. indica) and $C$. sativa (C. sativa subsp. sativa) occurred in the Middle Pleistocene approximately $1 \mathrm{Ma}$ (McPartland 2018). These authors noted that there is a gap of ca. 8 million years between the age of origin estimated by the molecular clock and the first fossil pollen encountered. In spite of this, they favored the mid-Oligocene age for the origin of Cannabis on the NE Tibetan Plateau (Fig. 4), assuming that, as demonstrated by the presence of Artemisia and other steppe elements, the region was covered by this type of vegetation, which would have been particularly well suited for the development of Cannabis, instead of favoring the EoceneOligocene boundary. A previous study using Bayesian calibration estimated the divergence between Cannabis and Humulus to have occurred $21 \mathrm{Ma}$ (Zerega et al. 2005), which is closer to the age of the first fossil pollen evidence.

According to pollen and seed fossil records, Cannabis would have experienced some expansion from its center of origin to Europe and East Asia before the onset of human evolution (Fig. 4). The suggested dispersal agents are water (hydrochory) and animals (zoochory) (McPartland 2018; McPartland et al. 2019). The first expansions occurred to the west (eastern Europe) and the east (NE China) during the Miocene-Pliocene. Most parts of the Asian continent were colonized by Cannabis during the Pleistocene, before the onset of the Neolithic, when humans domesticated the plant. The case of Europe is discussed later in more detail. During the Pleistocene (the last 2.6 million years), glacial-interglacial recurrence could have contributed to Cannabis diversification without human intervention. It has been suggested that Cannabis underwent recurrent range contractions (glacials) and expansions (interglacials) that facilitated allopatric processes, possibly leading to the differentiation between the European (C. sativa subsp. sativa) and Asian (C. sativa subsp. indica) subspecies, which diverged nearly $1 \mathrm{Ma}$ (Clarke and Merlin 2013; McPartland 2020). The first is considered the putative hemp ancestor (PHA), and the second is the putative drug ancestor (PDA) (Clarke and Merlin 2013).

\section{Domestication and diffusion}

In addition to fossils and DNA phylogenies, archaeological evidence is of paramount importance to reconstruct domestication and anthropogenic diffusion trends within Cannabis. The main types of evidence of Cannabis from archaeological sites are seeds, fibers, fiber/seed impressions, carbonized remains, phytoliths and chemical remains. During the historical period, written and graphic documents are also of fundamental help (Clarke and Merlin 2013). In this case, pollen identification has some additional clues related to its abundance in sediments, as Cannabis produces much more pollen than Humulus, which is usually underrepresented (Lewis et al. 1983). This is especially useful in cases of very high percentages of this pollen type, which are difficult to explain unless the sediments come from a former hemp-retting site. Indeed, when flowering male hemp plants are soaked in a retting pond to separate the fibers from the stalk, large quantities of pollen settle into pond sediments. In these situations, the percentages of Cannabis pollen in sediments may reach $80-90 \%$ of the 
total, but percentages over $15 \%$ or $25 \%$ have been considered sufficient to infer hemp retting (Peglar 1993; Mercuri et al. 2002; Demske et al. 2016; McPartland et al. 2019). The anemophylous pollen of Cannabis may be transported long distances; therefore, the finding of a few grains or their scattered occurrence throughout a stratigraphic section is not necessarily evidence for the local presence of the parent plant.

After a thorough review of the available historical evidence, Clarke and Merlin (2013) subdivided human-mediated Cannabis dispersal within and beyond Eurasia into six phases: 1 ) primary dispersal across Eurasia (10,000-2000 yr BP), 2) spread into Africa and SE Asia (2000$500 \mathrm{yr}$ BP), 3) diffusion into the Americas from Europe (1545-1800 CE), 4) diffusion to the Americas from Europe and Asia (1800-1945), 5) expansion after World War II (1945-1990), and 6) proliferation of industrial hemp (1990 CE to present). In the first phase, paleolithic nomadic peoples - who were expanding their range during the postglacial ice retreat - could have contributed, either consciously or accidentally, to the dispersal of the wild hemp (PHA) and drug (PDA) precursors from their corresponding distribution areas located in the Caucasus region and SE China, respectively (Fig. 5). This was the onset of differentiation of the four major Cannabis biotypes. NLH evolved from the PHA via an intermediate form known as the NLH ancestor (NLHA), whereas NLD and BLD originated from the PDA through the intermediate ancestral form called the NLDA. BLH could also have evolved from isolated PDA populations in NE China. The second phase coincided with the expansion of the Arab Empire into Africa and the Indian Empire into SE Asia. These cultures used Cannabis mainly as a drug and introduced the NLD biotype in their dominions, primarily through adventurers and traders. After the initial introductions, migrants and traders spread the NLD biotype across much of Africa and Asia, whereas the hemp biotype (NLH) remained restricted to Europe until the colonization of the Americas (Fig. 5).

Diffusion into the New World (phase 3 ) occurred during European colonization and consisted mainly of the production of hemp (NLH) for cordage, cloth and seed (Fig. 6). It is speculated whether Vikings could have carried hemp to North America in pre-Columbian times, but there is no evidence for a sound assessment. In addition to domestic uses, hemp cultivation was stimulated by European governments of the colonizing countries to provide their sailing ships with ropes and sails. During this phase (1545-1800 CE), drug biotypes remained in the Old World, where the African expansion of NLD continued. It was not until the middle $1800 \mathrm{~s}$ CE (phase 4) that Asian hemp (BLH) was introduced in North America through the Pacific Ocean (Fig. 6) to replace the inferior European hemp (NLH) in terms of fiber quality. The first psychoactive biotypes (NLD) were introduced from India into the Americas (mainly Latin America) by indentured laborers following the abolition of slavery in 1834.

After World War II (1945-1949), Cannabis cultivation and use were prohibited at the international level, which signified the end of legal diffusion of this plant and initiated the fifth spreading phase (Fig. 6). The illegal traffic of marijuana (NLD) for recreational use did not stop but has experienced a significant increase since the 1960s. Most producers of clandestine Cannabis were from Africa, Asia and Latin America, which inadvertently exported seeds to the main consuming centers from Europe and North America, where local cultivation attempts began. In the 1970s, Asian varieties of BLD were introduced into North America and western Europe, where the cultivation of NLD x BLD hybrids flourished.

During the last three decades (phase 6), Cannabis prosecution has generated new cultivation and dispersal modes to avoid legal detection. At the same time, renewed economic interest in hemp fiber has been sparked, which has promoted the legal industrial cultivation of hemp. Medical applications have also increased by artificial selection toward varieties with increased THC and other cannabinoids. New varieties have been created by hybridization of NLH and BLH 
biotypes aimed at expanding hemp cultivation to equatorial areas where European NLH does not grow well. Regarding drugs, the production of NLD/BLD hybrids has also increased and disseminated worldwide, and vegetative indoor cultivation of these hybrids has proliferated.

As a result, the global genetic diversity of both hemp and drug forms experienced a significant reduction in comparison with the 1970s and 1980s, when the different biotypes were cultivated by traditional farmers in isolated geographic habitats.

The dispersion model of Clarke and Merlin (2013) assumes two centers of domestication, one in the Caucasus, where the ancestor of hemp fiber domesticated biotypes evolved, and another in SE China, the place where the precursor of narcotic domesticates originated (Fig. 5). The idea of at least two domestication centers situated in Europe and Asia is supported by archaeobotanical studies using pollen, seeds and fibers (Long et al. 2007; McPartland et al. 2018). This contrasts with the view that domestication occurred in a single region. For example, Small (2015) suggested that Cannabis was domesticated in the northern Caspian Sea (not far from the Caucasus region) and that the four different domesticated groups were transported to other parts of the world during the last millennium. These four groups coincide with the abovementioned biotypes NLH (Europe), BLH (E Asia), NLD (South-Central Asia) and BLD (Afghanistan). Others have proposed that Cannabis was domesticated in Central Asia (Mongolia-N China) by 12,000 BCE (ca. 10,000 yr BP), which would place Cannabis among the oldest human domesticates (Warf 2014). A recent genome-wide phylogeographic study supports a unique center of domestication in East Asia (China), from which all biotypes would have emerged and dispersed throughout the world (Ren et al. 2021). According to this analysis, early domesticated ancestors of hemp and drug types diverged from wild Cannabis ca. 12,000 $\mathrm{yr} \mathrm{BP}$, which indicates that the species had already been domesticated by early Neolithic times.

The debate regarding the Cannabis center of domestication has paralleled the taxonomic controversy on Cannabis species that, as seen before, was already active by the time of Linnaeus and Lamarck. See, for example, Clarke and Merlin (2013 2016) and Small (2015) for more details on this long-standing discussion. Whether single or multiple centers of Cannabis domestication occurred has profound implications for the tempo and mode of Cannabis diffusion in Eurasia, where the plant evolved and was domesticated. As mentioned above, diffusion to other continents occurred relatively recently and is well documented historically. This paper focuses on Europe and, especially, the Iberian Peninsula, which are analyzed in more detail.

\section{Cannabis in Europe}

According to the single center of domestication hypothesis, European Cannabis would have been carried by humans from Asia already in a cultivated form. However, the finding of Pleistocene Cannabis pollen across Europe suggests that this plant had arrived to this continent before its domestication, and therefore, the plant had also been domesticated in Europe. Using the assemblage approach for the identification of $C$. sativa pollen explained above (Fig. 2), McPartland et al. (2018) performed a meta-analysis on nearly 480 sites and demonstrated that this pollen was widespread across Europe during the Pleistocene prior to human agency (Fig. 7). According to the same authors, no evident signs of Cannabis cultivation have been found either in the pollen or in the archaeological record for most of the European Neolithic. The first palynological evidence for potential Cannabis cultivation appeared in present-day Bulgaria during the late Neolithic-Copper age and expanded during the Bronze and Iron ages (Fig. 7). Cannabis cultivation expanded across the entire continent between 2000 and 800 yr BP during the Roman Empire and the Early Middle Ages. These results were supported by a further meta-analysis of archaeological evidence (textiles, cordage, fiber, seeds, pottery impressions and phytoliths) from almost 140 sites (McPartland and Hegman 
2018). These authors concluded that Cannabis dispersed from Asia to Europe in its wild form during the Pleistocene and was domesticated in situ during the Copper and Bronze ages. This challenges the single-site domestication hypothesis, according to which Cannabis would have been domesticated in Asia and expanded worldwide as a cultivated plant.

The European domestication of Cannabis is consistent with the former view of Clarke and Merlin (2013), who proposed that the precursor of the European NLH biotype - the wild PHA, related to $C$. sativa subsp. sativa - would have been centered in the Caucasus region and expanded to western Eurasia and eastern Europe during the Pleistocene (compare Fig. 7 with Fig. 5, phase 1). Chronologically, this possibility also seems plausible, as $C$. sativa subsp. sativa diverged from its Asian sister $C$. sativa subsp. indica in the Middle Pleistocene, approximately 1 Ma (McPartland 2018), and the European records of wild Cannabis are younger than this divergence. In addition, the ages of these wild European records show consistent westward and southward dispersal patterns during the Middle and Late Pleistocene, with younger postglacial records situated in the west and south (Fig. 7). Notably, the European domestication of Cannabis (7-5 kyr BP) estimated from pollen and archaeological records (McPartland et al. 2018; McParland and Hegman 2018) occurred after the European Neolithic and much later than Asian domestication (12 kyr BP), as estimated by calibrated phylogenetic trees (Ren et al. 2021).

\section{The Iberian Peninsula}

The Iberian Peninsula (hereafter IP) is a key biogeographic region due to its intermediate position between the Eurosiberian and Mediterranean bioclimatic regions (Loidi 2017). The Mediterranean biome and its climatic features, which are the most widespread across the IP (Fig. 8), are well suited for the growth of Cannabis. In cultural terms, the IP is also a strategic spot due to its geographic location, which has promoted the interaction of a diversity of cultures over prehistoric and historic times, favored by numerous and varied land and sea connections. Therefore, it might be expected that the IP would also be a relevant place for the study of a plant such as Cannabis, which has been subjected to intensive and extensive natural and human-mediated dissemination. It should be noted, however, that the IP is far from any proposed center of origin for Cannabis, and the wild form of this plant seems to have reached the peninsula only in postglacial times (after $18.5 \mathrm{kyr}$ BP), after a long journey from the Caucasus region (Figs. 4 to 6). Similarly, the former continental-scale meta-analysis of fossil pollen and archaeological evidence (McPartland et al. 2018; McParland and Hegman 2018) indicates that the IP was among the last European areas - along with the British Isles and the Scandinavian region - where Cannabis was cultivated, and this occurred during the Roman Empire and the Early Middle Ages (2000-800 yr BP).

However, these continental-wide analyses include only a few IP sites in their compilations. For example, Clarke and Merlin (2013) mentioned a single, yet representative, site (Lake Estanya; Fig. 8) where Cannabis was submitted to intensive cultivation and retting and used it to propose the arrival of Cannabis to the IP by 600 CE. McPartland et al. (2018) retrieved their Iberian sites from the European Pollen Database

(http://www.europeanpollendatabase.net/index.php) and other internet facilities and considered 10 IP sites, including two from the Balearic Islands (Fig. 8). In this way, although the incoming of Cannabis to the IP may be placed within a rather general European context, the precise timing and pathways of arrival, as well as the internal and external dispersal trends, remain largely unknown. Due to the peculiar climatic, biogeographic and cultural features of the IP mentioned above, a thorough survey focused on this specific region to reconstruct Cannabis history is worth attempting. 
The potential of the IP for providing useful information in this sense is high, as demonstrated by some studies that have recorded relevant historical developments in the hemp industry based on pollen analyses of lake sediments. Among them, the most significant examples were found in lakes Estanya and Montcortès (Fig. 8), where hemp was exploited since the Early Middle Ages. The advantage of these sites is that the amount of Cannabis pollen deposited in the sediments is consistent with local cultivation and/or retting rather than with dispersal from regional and long-distance sources. Indeed, some aerobiological studies have demonstrated that relevant amounts of north-African Cannabis pollen can be transported to the southern IP in a few days (Cabezudo et al. 1997). Similarly, a recent study of modern sedimentation in Lake Montcortès (Fig. 8) recorded significant percentages of Cannabis pollen, but the parent plant was absent from the region (Rull et al. 2017). This long-distance dispersal ability implies that only the presence of this pollen is not sufficient to infer the local occurrence of Cannabis populations. However, this is not the case for Estanya and Montocortès, as we discuss in the following section.

In the sediments of Lake Estanya, the first appearance of Cannabaceae pollen was recorded ca. 600 CE (Riera et al. 2004) during the Early Middle Ages (Fig. 9). From then, the record was continuous until the 1990s. Hemp pollen was accompanied by other cultivated plants, such as Olea (olive tree), Secale (rye) and other undifferentiated cereal pollen. Hemp percentages remained relatively stable $(<10 \%)$ until the $14^{\text {th }}$ century, when they underwent a significant increase of up to $25 \%$ around the middle of the $18^{\text {th }}$ century (Modern Age). This increase was interpreted in terms of hemp retting in the lake, coinciding with a local increase in the cultivation of this plant (Riera et al. 2004). This phase coincided with the maximum hemp production in Spain due to the high demand from the Spanish navy (Riera et al. 2006). After these dates, hemp pollen decreased abruptly to values below $10 \%$ during the $20^{\text {th }}$ century. The authors attributed this hemp crisis to a general decrease in cultivation due to the depopulation of the area during the first half of the $20^{\text {th }}$ century.

The first pollen records of Cannabis pollen in Lake Montcortès sediments also occurred at approximately $600 \mathrm{CE}$ and coincided with the disappearance of cereals (Fig. 10), which indicates a shift in local cultivation practices from cereals to hemp (Rull et al. 2021). Further increases in wild grasses and weeds such as Artemisia (mugworts) and Plantago (plantains) are consistent with the expansion of pastures. Hemp pollen experienced three main phases of abundance, separated by two phases of scarcity. The first two phases (ca. 600-750 CE and ca. 850-250 CE) were interpreted in terms of low-intensity cultivation/retting to cover local needs for fiber. The third phase, however, was characterized by significantly high abundances (50$60 \%$ ) and was difficult to explain in terms of only local consumption (Rull et al. 2021). As in Lake Estanya, this phase (ca 1550-1850 CE) was coeval with the maximum development of the Spanish navy and, as a consequence, of hemp cultivation across the entire country. The same abrupt decrease in hemp pollen was recorded at the end of the $19^{\text {th }}$ century, which has been related to the dismantling of the royal navy, the onset of hemp importation from other countries, the substitution of hemp fiber by other materials such as cotton and synthetic fibers, and the decrease in human pressure (Rull and Vegas-Vilarrúbia 2004; Trapote et al. 2018). The further increase in hemp pollen in the late $20^{\text {th }}$ century may have been due to the renewed interest in hemp, likely favored by EU subsides (Trapote et al. 2018).

The combination of the meta-analysis discussed above (Fig. 7) and the case studies of Estanya and Montcortès may suggest that wild Cannabis reached the IP during the postglacial period (18.5-15 kyr BP) and that cultivated Cannabis entered much later, by 600 CE. Notably, both entries would have proceeded from the northeastern sector. However, in the present state of knowledge, it is still premature to confirm these assessments. The lag of sufficient localities also hinders knowing what happened on the IP with Cannabis during the large gap between 
postgacial times and the Middle Ages. The development of a thorough database for the IP, as a basis for further meta-analyses, is essential to understand when and how wild and cultivated Cannabis reached the IP, as well as what happened since those times.

In addition to the information available from the above reviews and meta-analyses, other sources of information should be accessed. For example, many other sites are available in the compilation by Carrión et al. (2012) that have not been included in the former studies. This compilation gathered almost all pollen records available for the IP by the time of publication and is now being updated with new studies developed during the last decade. There are also other individual sites with Cannabis/Humulus pollen that need more bibliographic research. A number of these studies are not easy to locate, as they are available only in dissertations and local journals. Finally, some studies do not include Cannabis/Humulus pollen in the diagrams due to its scarcity, but the authors have data in their counting sheets and they can be recovered. Therefore, personal contact with palynologists working on the IP is also needed. All these information sources, along with others that may be located further, should be included in an IP-wide study. 
Table 1. The four biotypes of cultivated Cannabis as defined by Clarke and Merlin (2016), following the criteria of Small (2015). See Fig. 1 for the present geographical distribution of these biotypes.

\begin{tabular}{|l|l|l|l|l|l|l|l|}
\hline Biotype & Name & Psychoactive & THC & CBD & Use & Origin & Diffusion \\
\hline NLH & $\begin{array}{l}\text { Narrow- } \\
\text { leaf } \\
\text { hemp }\end{array}$ & Rarely & Low & High & Fiber/oil & Europe & New World \\
\hline BLH & $\begin{array}{l}\text { Broad- } \\
\text { leaf } \\
\text { hemp }\end{array}$ & Mildly & Low/Moderate & High & Fiber/oil & East Asia & $\begin{array}{l}\text { Europe, } \\
\text { New World }\end{array}$ \\
\hline NLD & $\begin{array}{l}\text { Narrow- } \\
\text { leaf drug }\end{array}$ & Very & High & Low/absent & Drug & South Asia & $\begin{array}{l}\text { Africa, } \\
\text { Europe, } \\
\text { Middle } \\
\text { East, New } \\
\text { World }\end{array}$ \\
\hline BLD & $\begin{array}{l}\text { Broad- } \\
\text { leaf drug }\end{array}$ & Moderately & Moderate/high & Moderate/high & Drug & Afghanistan & $\begin{array}{l}\text { Europe, } \\
\text { New World }\end{array}$ \\
\hline
\end{tabular}

Table 2. Examples of the variety of uses of the different parts of the $C$. sativa plants. Modified from Clarke and Merlin (2016).

\begin{tabular}{|l|l|l|}
\hline Plant parts & Use category & Material type or benefits \\
\hline Stem bark & Cordage & Long cellulose fibers \\
\hline Stem fiber & $\begin{array}{l}\text { Cordage, woven textiles, } \\
\text { building materials }\end{array}$ & Long cellulose fibers, concrete reinforcement \\
\hline Wood/bark & $\begin{array}{l}\text { Paper, building materials, } \\
\text { animal bedding, fuel }\end{array}$ & $\begin{array}{l}\text { Long/short cellulose fibers, chip board, } \\
\text { concrete matrix, heat, light }\end{array}$ \\
\hline Female flowers/seeds & Medicinal & $\begin{array}{l}\text { Herbal remedies, pharmaceuticals, } \\
\text { nutraceuticals }\end{array}$ \\
\hline $\begin{array}{l}\text { Female flowers and } \\
\text { associated resin glands }\end{array}$ & Recreational drugs & Marijuana, hashish \\
\hline Seeds (oil) & $\begin{array}{l}\text { Human food, industrial } \\
\text { feedstock, fuel }\end{array}$ & $\begin{array}{l}\text { Proteins/essential fatty acids, paint/plastic } \\
\text { manufacture }\end{array}$ \\
\hline Seeds (cake), foliage & Animal feed & Proteins and essential fatty acids \\
\hline All parts & Ritual and social & Healing, life cycle rituals, inebriation \\
\hline Plant-people interplay & Aesthetic & Intrinsic beauty of the plant \\
\hline Genus & Educational & $\begin{array}{l}\text { Iconic example of an economic plant and its } \\
\text { ancient human relationships }\end{array}$ \\
\hline
\end{tabular}




\section{References}

Allen JRM, Huntley B, Watts WA (1996) The vegetation and climate of northwest Iberia over the last 14000 yr. J Quat Sci 11:125-147

Alonso N, Juan J (1994) Fibras de lino en las piletas del poblado del Coll del Moro (Gandesa, Terra Alta): estudio paleoetnobotánico. Trab Prehist 51:137-142

Balant M, Gras A, Gálvez F, Garnatje T, Vallès J, Vitales D (2021) CANNUSE, a database of traditionak Cannabis uses - an opportunity for new research. Database 2021:baab024

Barcaccia G, Palumbo F, Scariolo F, Vannozzi A, Borin M, Bona S (2020) Potentials and challenges of genomics for breeding cannabis cultivars. Front Plant Sci 11:573299

Burjachs F, Pérez-Obiol R, Roure JM, Julià R (1994) Dinámica de la vegetación durante el Holoceno en la isla de Mallorca. Trabajos de Palinología Básica y Aplicada - X Simposio de Palinología APLE, Valencia, pp. 199-210

Cabezudo B, Recio M, Sánchez-Laulhé JM, Trigo MM, Toro FJ, Polvorinos F (1997) Atmospheric transportation of marihuana pollen from North Africa to the Soutwest of Europe. Atmos Environ 31:3323-3328

Carrión JS (2012) Paleoflora y Paleovegetación de la Península Ibérica e Islas Baleares: Plioceno-Cuaternario. Fundación Séneca, Murcia

Clarke RC, Merlin MD (2013) Cannabis: Evolution and Ethnobotany. University of California Press, Los Angeles

Clarke RC, Merlin MD (2016) Cannabis domestication, breeding history, present-day genetic diversity, and future prospects. Crit Rev Plant Sci 35:293-327

Currás A (2012) Estudio sobre la evolución de paisajes mediterráneos continentales en Lleida y Guadalajara durante los últimos 3000 años a partir de las secuencias polínicas de Ivars, Somolinos y Cañamares. PhD dissertation, University of Barcelona

Demske D, Tarasov PE, Leipe C, Kotlia BS, Joshi LM, Long TW (2016) Record of vegetation, climate change, human impact and retting of hemp in Garhwal Himalaya (India) during the past 4600 years. Holocene 26:1661-1675

Duvall C (2014) Cannabis. Reaktion, London

Ejarque A, Miras Y, Riera S, Palet JM, Orengo HA (2010) Testing micro-regional variability in the Holocene shaping of high mountain cultural landscapes: a palaeoenvironmental casestudy in the eastern Pyrenees. J Archaeol Sci 37:1468-1479

Fike J (2016) Industrial hemp: renewed opportunities for an ancient crop. Crit Rev Plant Sci 35:406-424

Finlayson C (2005) Biogeography and evolution of the genus Homo. Trends Ecol Evol 20:457463

Fleming MP, Clarke RC (1998) Physical evidence for the antiquity of Cannabis sativa L. J Int Hemp Assoc 5:80-92

Franco-Mújica F, García Antón M, Sainz Ollero H (1998) Vegetation dynamics and human impact in the Sierra de Guadarrama, Central System, Spain. Holocene 8:69-82

Godwin H (1967) Pollen-analytical evidence for the cultivation of Cannabis in England. Rev Palaeobot Palynol 4:71-80

Gray DJ, Baker H, Clancy K, Clarke RC, deCesare K, Fike J, Gibbs MJ, Grotenhermen F, Kane NC, et al. (2016a) Current and future needs and applications of Cannabis. Crit Rev Plant Sci 35:425-426

Gray DJ, Clarke RC, Trigiano RN (2016b) Introduction to the special issue on Cannabis. Crit Rev Plant Sci 35:289-292

Grotenhermen F, Müller-Vahl K (2016) Medicinal uses of marijuana and cannabinoids. Crit Rev Plant Sci 35:378-405

Kovalchuck I, Pellino M, Rigault P, van Velzen R, Ebersbach J, Ashnest JR, Mau M, Schranz ME, Alcorn J, Laprairie RB, McKay JK, Burbridge C, Schneider D, Vergara D, Kane NC, Sharbel TF (2020) The genomics of Cannabis and its close relatives. Annu Rev Plant Biol 71:713-739 
Lewis WH, Prathiba V, Zengler VE (1983) Airoborne and Allergenic Pollen of North America. Johns Hopkins University Press, Baltimore

Loidi J (2017) The Vegetation of the Iberian Peninsula. Springer, Cham

Long TW, Wagner M, Demske D, Laipe C, Tarasov PE (2017) Cannabis in Eurasia: origin of human use and Bronze age trans-continental connections. Veg Hist Archaeobot 26:245258

López P (1988) Estudio polínico de seis yacimientos del sureste español. Trab Prehist 45:335345

Lynch RC, Vergara D, Tittes S, White K, Schwartz CJ, Gibbs MJ, Ruthenburg TC, deCesare K, Land DP, Kane NC (2016) Genomic and chemical diversity in Cannabis. Crit Rev Plant Sci 35:349-363

Mercuri AM, Accorsi CA and Bandini M (2002) The long history of Cannabis and its cultivation by the Romans in central Italy, shown by pollen records from Lago Albano and Lago di Nemi. Veg Hist Archaeobot 11:263-276

Merlin MD (1972) Man and Marijuana: Some Aspects of their Ancient Relationship. Fairleigh Dickinson University, Rutherford

McPartland JM (2018) Cannabis systematics at the levels of family, genus and species. Cannabis Cannabinoid Res 3:203-212

McPartland JM (2020) Cannabis: the plant, its evolution, and its genetics - with an emphasis on Italy. Rendiconti Lincei - Sci Fis Nat 31:939-948

McPartland JM, Hegman W (2018) Cannabis utilization and diffusion patterns in prehistoric Europe: a critical analysis of archaeological evidence. Veg Hist Archaeobot 27:627-634

McPartland JM, Guy GW, Hegman W (2018) Cannabis is indigenous to Europe and cultivation began during the Copper or Bronze age: a probabilistic synthesis of fossil pollen studies. Veg Hist Archaeobot 27:635-648

McPartland JM, Hegman W, Long TW (2019) Cannabis in Asia: its center of origin and early cultivation, based on a synthesis of subfossil pollen and archaeological studies. Veg Hist Archaeobot 28:691-702

Pantaleón-Cano J, YII E-I, Pérez-Obiol R, Roure JM (2003) Palynological evidence for vegetational history in semi-arid areas of the western Mediterranean (Almería, Spain). Holocene 13:109-119

Peglar SM (1993) The development of the cultural landscape around Diss Mere, Norfolk, UK., during the past 7000 years. Rev Palaeobot Palynol 76:1-47

Pérez-Obiol R, Julià R (1994) Climatic change on the Iberian Peninsula recorded in a 30,000-yr pollen record from Lake Banyoles. Quat Res 41:91-98

Rahn B, Pearson BJ, Trigiano RN, Gray DJ (2016) The derivation of modern cannabis varieties. Crit Rev Plant Sci 35:328-348

Ren G, Zhang X, Li Y, Ridout K, Serrano ML, Yang Y, Liu A, Ravikanth G, Nawaz MA, Mumtaz AS, Salamin N, Fumagalli L (2021) Large-scale whole-genome resequencing unravels the domestication history of Cannabis sativa. Sci Adv 7:eabg2286

Riera S, Wansard G, Julià R (2004) 2000-year environmental history of a karstic lake in the Mediterranean Pre-Pyrenees: the Estanya lakes (Spain). Catena 55:293-324

Riera S, López-Sáez JA, Julià R (2006) Lake responses to historical land use changes in northern Spain: the contribution of non-pollen palynomorphs in a multiproxy study. Rev Palaeobot Palynol 141:127-137

Rull V, Vegas-Vilarrúbia T (2014) Preliminary report on a mid-19 ${ }^{\text {th }}$ century Cannabis pollen peak in NE Spain: historical context and potential chronological significance. Holocene 24:13781383

Rull V, González-Sampériz P, Corella JP, Morellón M, Giralt S (2011) Vegetation changes in the southern Pyrenean flank during the last millennium in relation to climate and human activities: the Montcortès lacustrine record. J Paleolimnol 46:387-404 
Rull V, Trapote MC, Safont E, Cañellas-Boltà N, Pérez-Zanón N, Sigró J, Buchaca T (2017) Seasonal patterns of pollen sedimentation in Lake Montcortès (Central Pyrenees) and potential applications to high-resolution paleoecology: a 2-year pilot study. J Paleolimnol 57:95-108

Rull V, Vegas-Vilarrúbia T, Corella JP, Trapote MC, Montoya E, Valero-Garcés B (2021) A unique Pyrenean varved record provides a detailed reconstruction of Mediterranean vegetation and land-use dynamics over the last three millennia. Quat Sci Rev 268:107128

Schultes RE (1969) Hallucinogens of plant origin. Science 163:245-254

Small E (2015) Evolution and classification of Cannabis sativa (marijuana, hemp) in relation to human utilization. Bot Rev 81:189-294

Trapote MC, Rull V, Giralt S, Corella JP, Montoya E, Vegas-Vilarrúbia T (2018) High-resolution (sub-decadal) pollen analysis of varved sediments from Lake Montcortès (southern Pyrenean flank): a fine-tuned record of landscape dynamics and human impact during the last 5000 years. Rev Palaeobot Palynol 259:207-222

Vergara D, Baker H, Clancy K, Keepers KJ, Mendieta JP, Pauli CS, Tittes SB, White KH, Kane N (2016) Genetic and genomic tools for Cannabis sativa. Crit Rev Plant Sci 35:364-377

Warf B (2014) High points: an historical geography of Cannabis. Geogr Rev 104:414-438

Wells RS (2002) The Journey of Man: A Genetic Odissey. Princeton University Press, Princeton.

Whittington G, Edwards KJ (1989) Problems in the interpretation of Cannabaceae pollen in the stratigraphic record. Pollen Spores 31:79-96

Whittington G, Gordon AD (1987) The differentiation of the pollen of Cannabis sativa L from that of Humulus lupinus L. Pollen Spores 29:111-120

YII, E-I, Pérez-Obiol R, Pantaleon-Cano J, Roure JM (1997) Palynological evidence for climatic change and human activity during the Holocene on Minorca (Balearic Islands). Quat Res 48:339-347

Zerega NJC, Clement WL, Datwyler SL, Weibben GD (2005) Biogeography and divergence times in the mulberry family (Moraceae). Mol Phylogenet Evol 37:402-416 


\section{Figure captions}

Figure 1. Worldwide distribution of the different Cannabis biotypes developed by humans (Table 1). Hemp biotypes are in red and drug biotypes in red. NLH, narrow-leaf hemp; BLH, broad-leaf hemp; NLD, narrow-leaf drug; BLD, broad-leaf drug; NLD/BLD, hybrid between NLD and BLD; PA?, putative Cannabis ancestor. Redrawn from Clarke and Merlin (2016).

Figure 2. Algorithm developed to differentiate between Cannabis and Humulus pollen in sedimentary records, using the assemblage approach. As explained in the text, crop pollen usually includes cereal and weed pollen. AP, arboreal pollen; NAP, non-arboreal pollen; PAC, steppe assemblage (Poaceae-Artemisia-Chenopodiaceae); ASP, forest assemblage (Alnus-SalixPopulus). Redrawn from McPartland et al. (2018).

Figure 3. Time-calibrated molecular DNA phylogenetic tree used for the estimation of the divergence rates within the Cannabaceae and some related families (molecular clock). Red dots are the nodes used for calibrating the phylogenetic tree using Humulus, Celtis, Morus and Ficus fossils of known age. Numbers are ages in million years before present (Ma). Redrawn and modified from McPartland (2018).

Figure 4. Center of origin (red dot) and preanthropic dispersal of Cannabis, based on fossil pollen data and the use of the assemblage algorithm explained above (Fig. 2). Dot colors indicate the age of first occurrences of Cannabis pollen (see legend), in million years before present (bold numbers) and in thousand years before present (normal numbers). Redrawn and modified from McPartland et al. (2019).

Figure 5. The first two phases of human-mediated Cannabis diffusion. As in Fig. 1, hemp biotypes are indicated by green letters and drug biotypes are in red letters. Redrawn and modified from Clarke and Merlin (2013).

Figure 6. Phases three to six of anthropogenic Cannabis expansion. As in Fig. 1, hemp biotypes are indicated by green letters and drug biotypes are in red letters. Redrawn and modified from Clarke and Merlin (2013).

Figure 7. Pleistocene (upper panel) and Holocene (lower panel) European pollen records consistent with Cannabis, according to the assemblage identification approach (Fig. 2). Note that, in the Pleistocene panel, post-glacial ages have been differentiated from the rest of Late Pleistocene ages. PHA is the precursor of the European Cannabis according to Clarke and Merlin (2013); compare with Fig. 5, phase 1. Ages in million years before present (bold numbers) and in thousand years before present (normal numbers). Raw data from McPartland et al. (2018).

Figure 8. Map of the Iberian Peninsula indicating the location of the sites included in the available reviews and meta-analyses (Clarke and Merlin 2013; McPartland and Hegman 2018; McPartland et al. 2018). The Eurosiberian bioclimatic region is in green and the Mediterranean region in yellow. The numbers in brackets above the site names are the age of the first appearance of the Cannabis/Humulus pollen, in kyr BP. Original references: Alcúdia (Burjachs et al. 1994); Andorra (Ejarque et al. 2010); Antas (Pantaleón-Cano et al. 2003); Algendar (Yll et al. 1997); Banyoles (Pérez-Obiol and Julià 1994); Coll del Moro (Alonso and Juan 1994); Estanya (Riera et al. 2004); La Roya (Allen et al. 1995); Montcortès (Rull et al. 2011); Rascafría (FrancoMújica et al. 1998); Somolinos (Currás 2021); Totana (López 1988). 
Figure 9. Pollen diagram of selected cultivated plants from Lake Estanya record, which was dated using radiocarbon and known historical events. Dashed lines are the percentage boundaries ( $15 \%$ and $25 \%$ ) proposed by different authors for inferring retting practices (see text). The red arrow indicates the first appearance of Cannabaceae pollen. The boundaries of the cultural phases are approximate. Redrawn and modified from Riera et al. (2004).

Figure 10. Pollen diagram of selected cultivated plants and weeds from Lake Montcortès sediments, which were dated up to ca. 3000 yr BP using varves. Dashed lines are the percentage boundaries ( $15 \%$ and $25 \%$ ) proposed by different authors for inferring retting practices (see text). The red arrow indicates the first appearance of Cannabis pollen. Modified from Rull et al. (2021). 


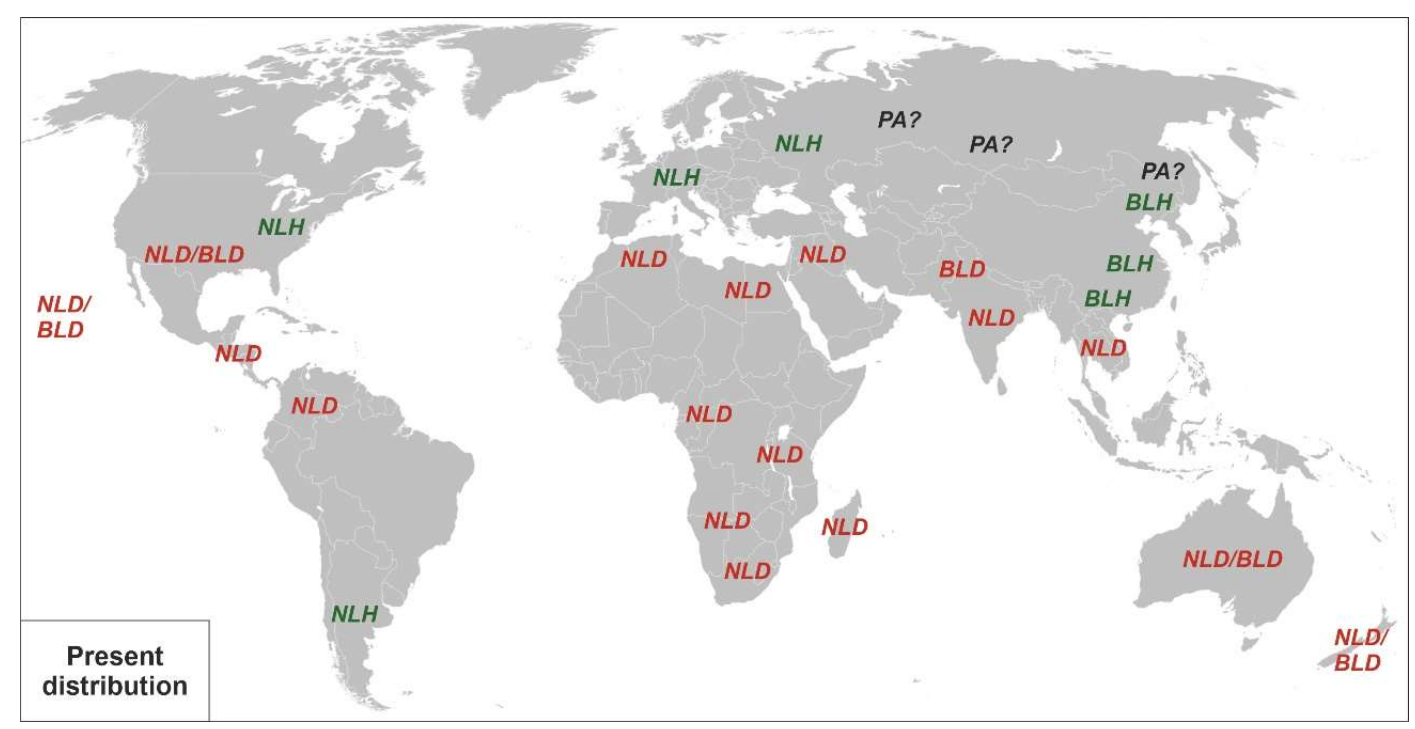

Figure 1

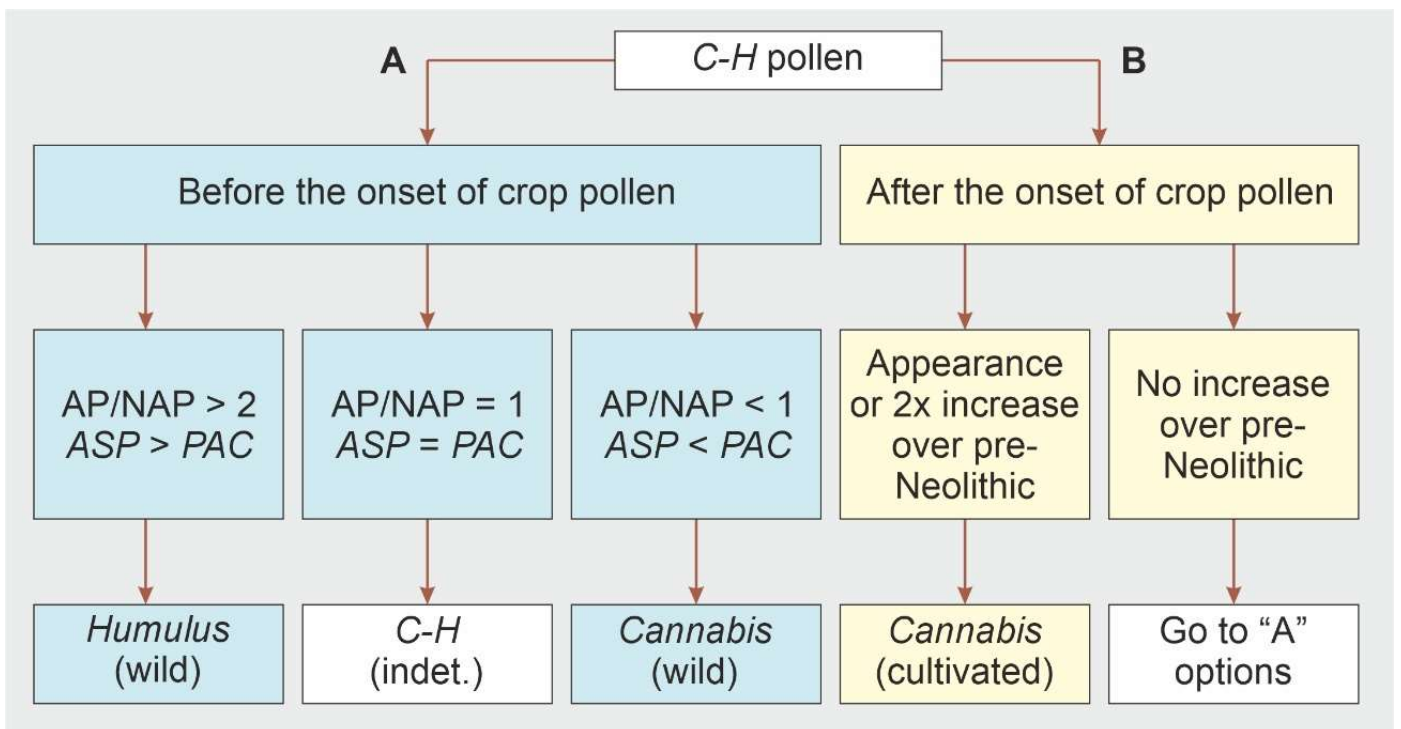

Figure 2 


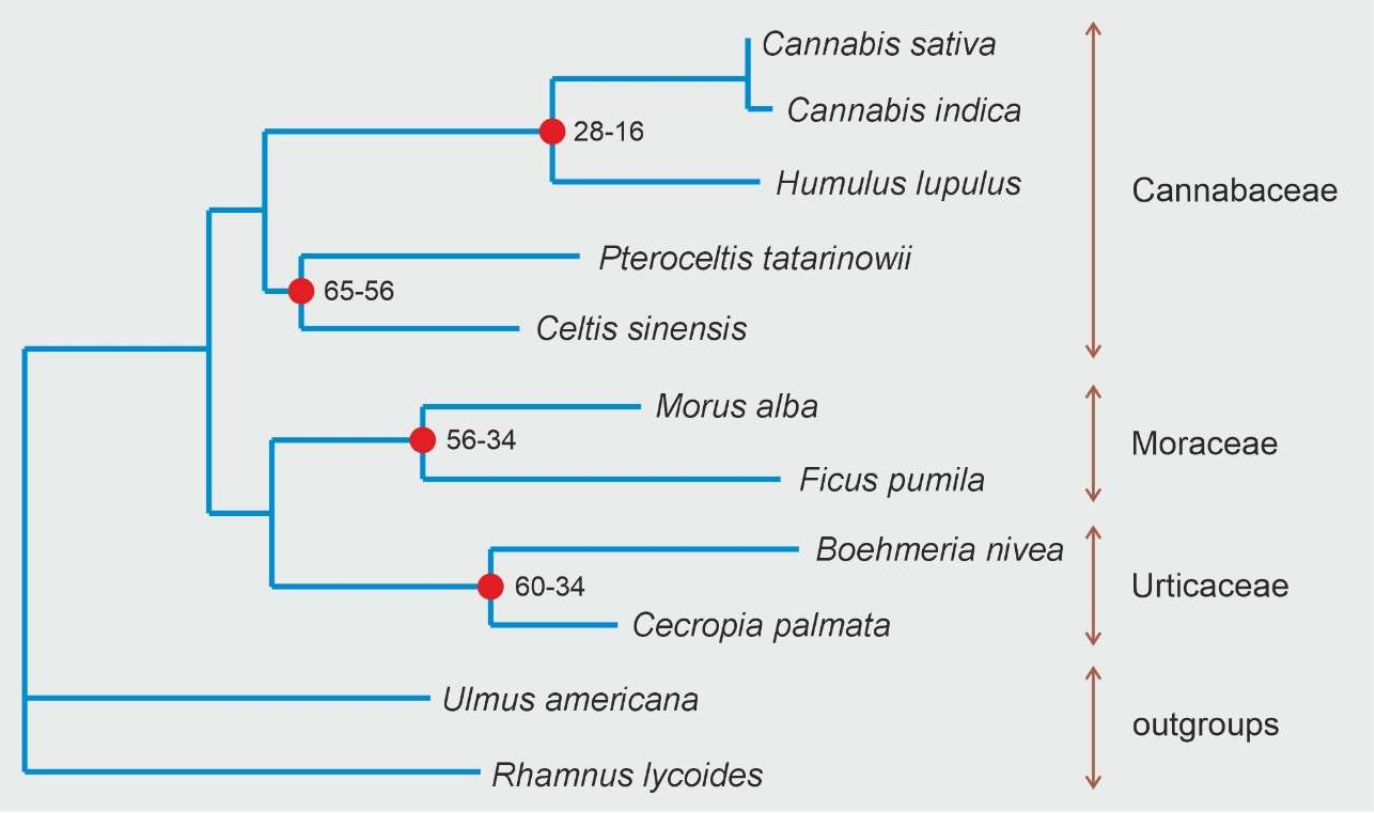

Figure 3

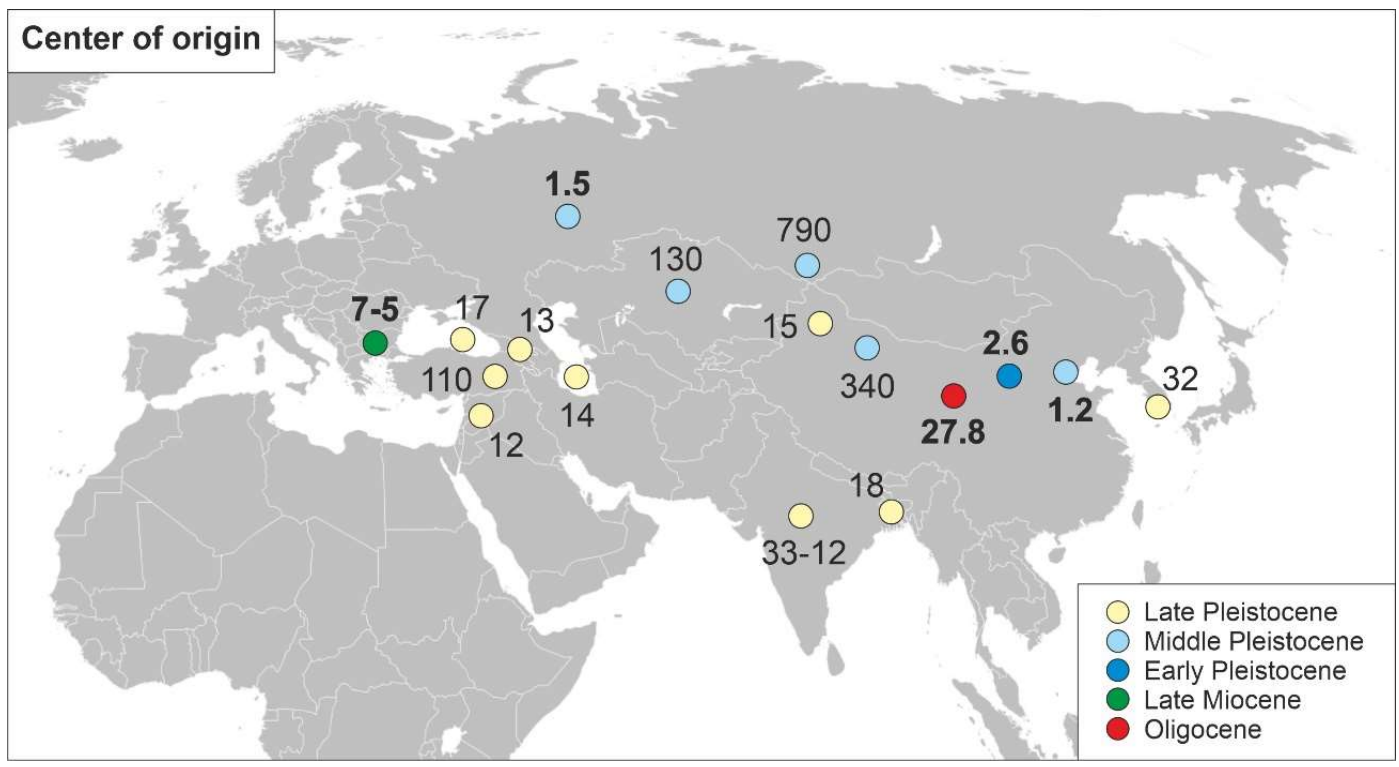

Figure 4 

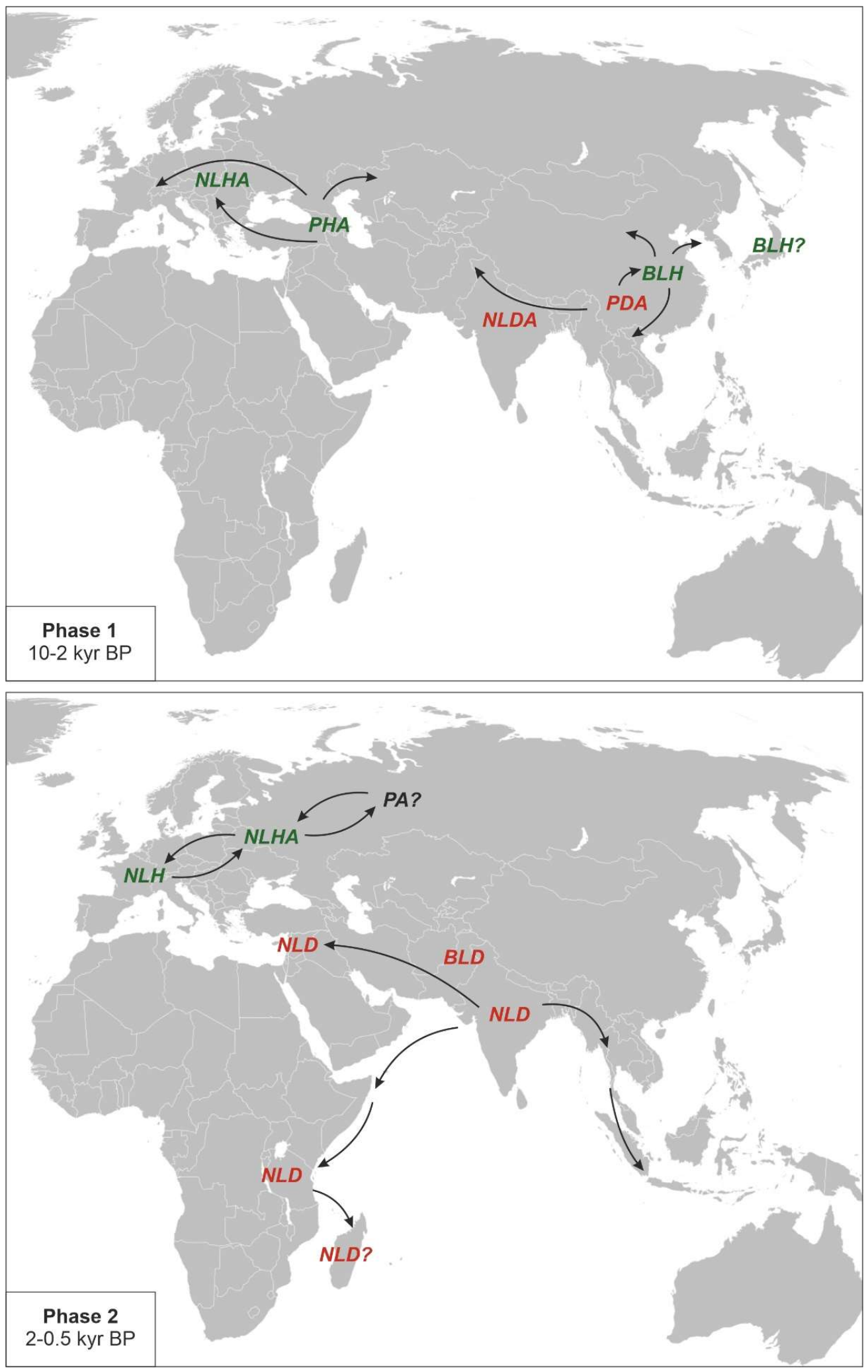

Figure 5 

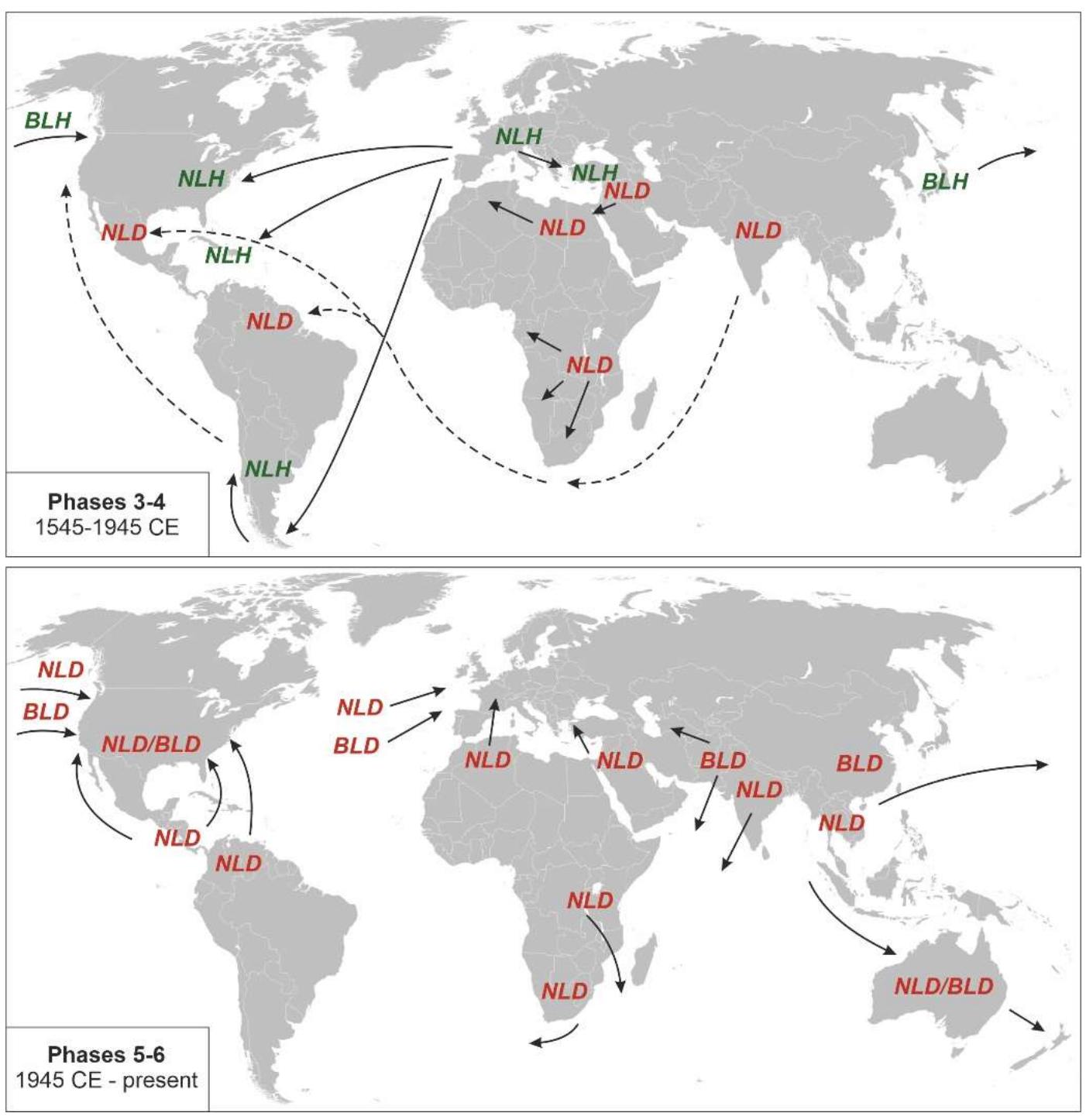

Figure 6 

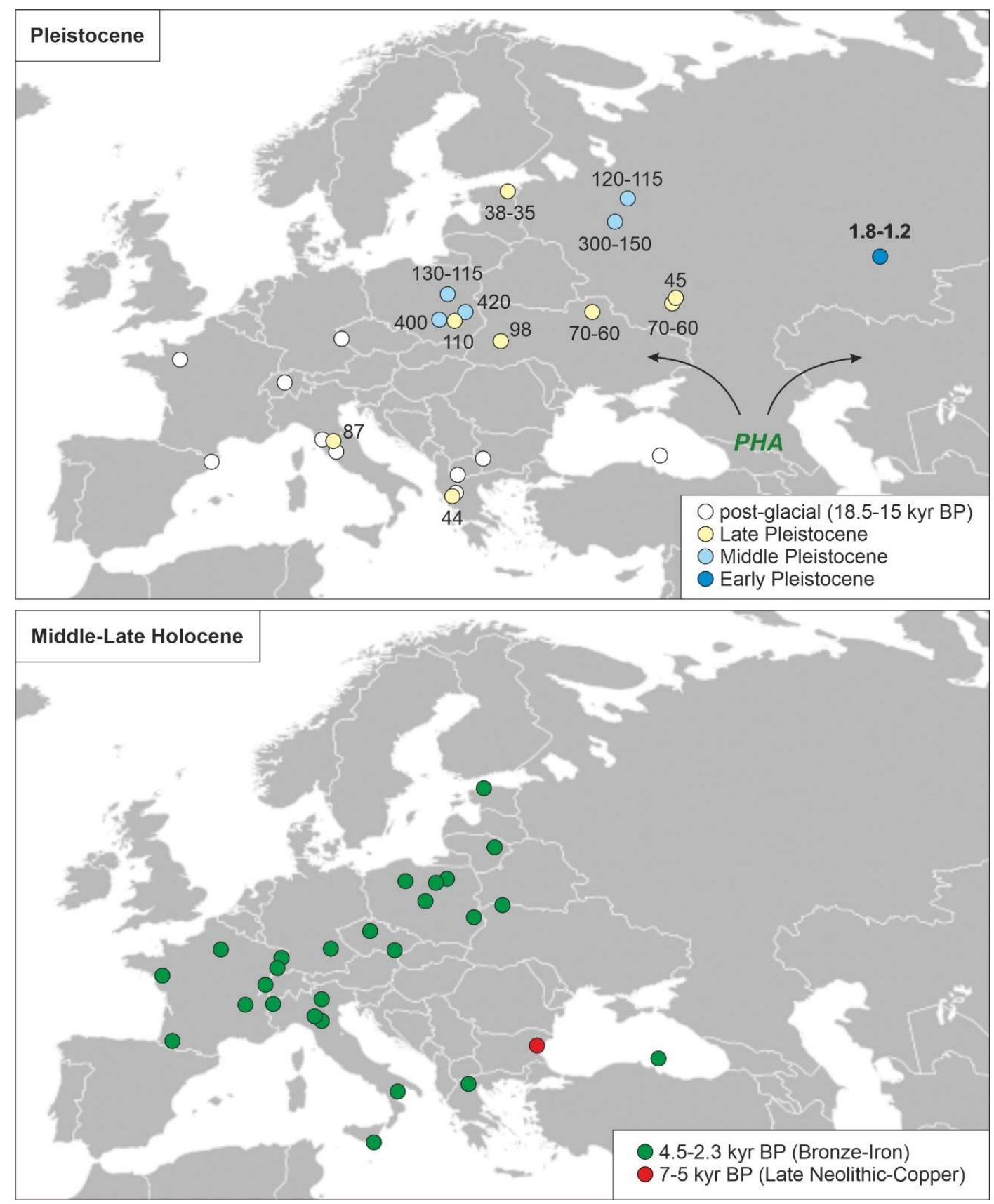

Figure 7 


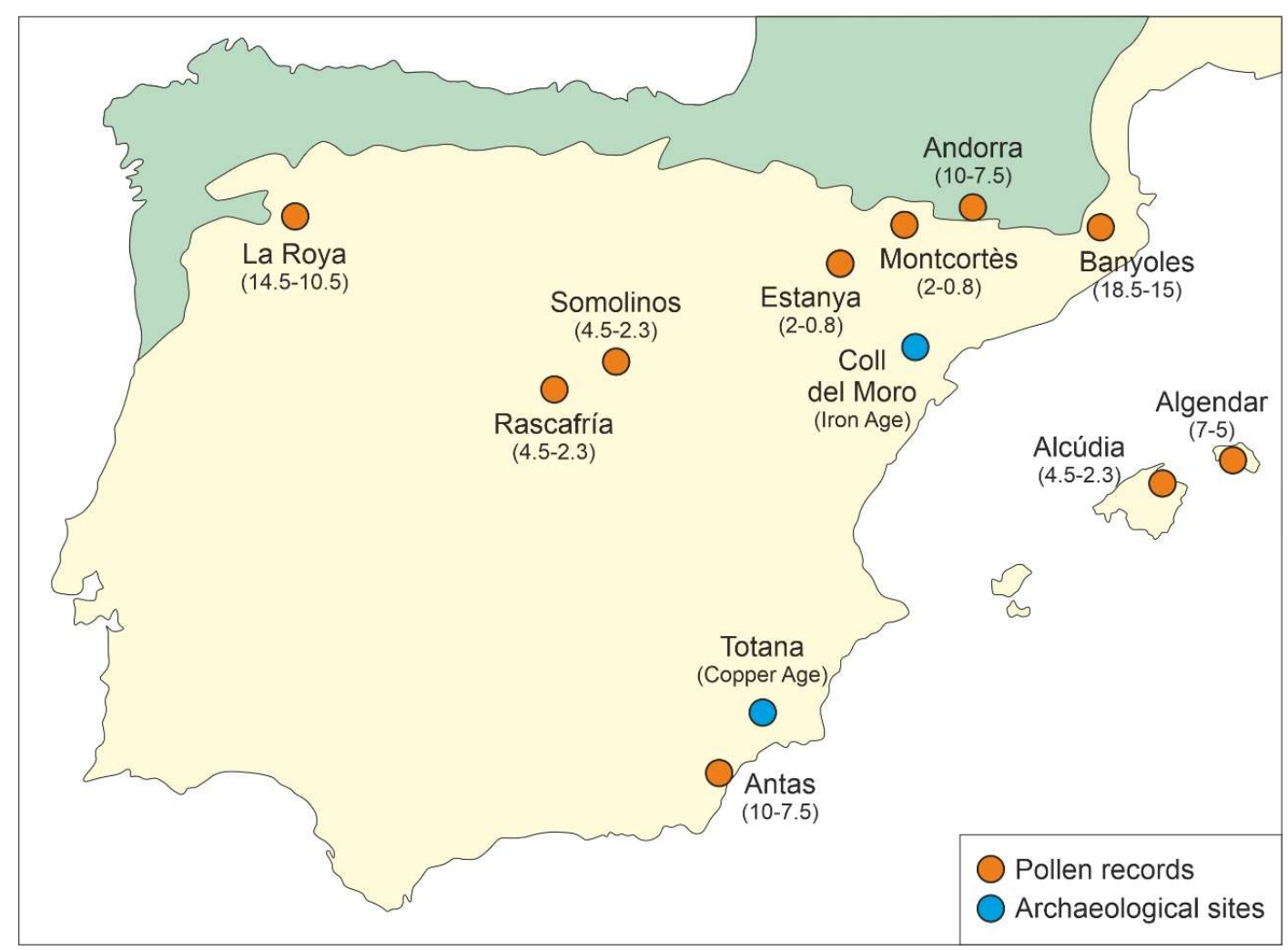

Figure 8 


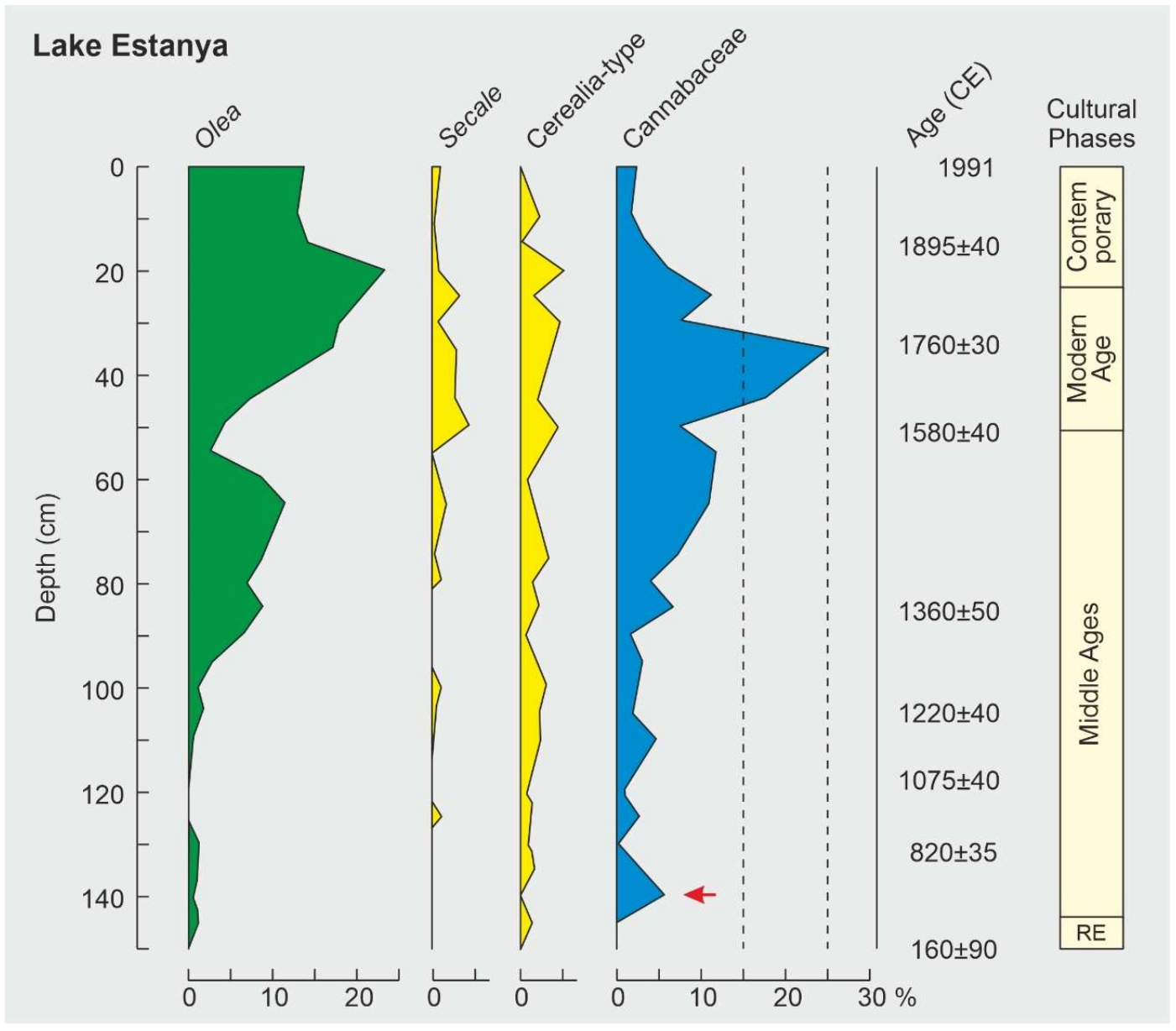

Figure 9 


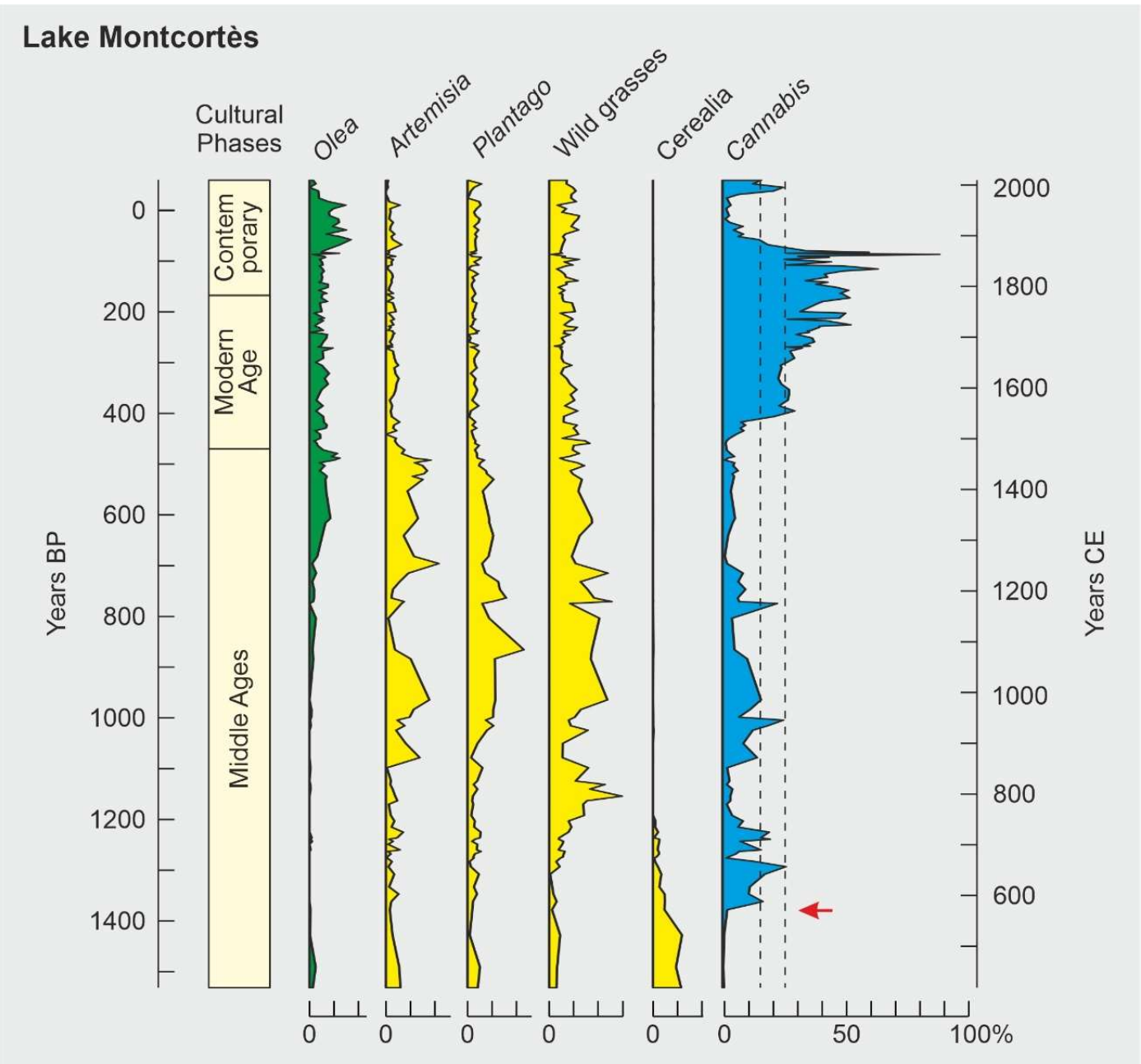

Figure 10 